Supporting Information for

\title{
Stable CdTe Photoanodes with Energetics Matching Those of a Coating Intermediate Band
}

\author{
Xiangyan Chen, ${ }^{\text {abc }}$ Xin Shen, ${ }^{\text {ac }}$ Shaohua Shen, ${ }^{* b}$ Matthew O. Reese, ${ }^{\mathrm{d}}$ and Shu $\mathrm{Hu}^{* a c}$ \\ ${ }^{a}$ Department of Chemical and Environmental Engineering, Yale University, New Haven, Connecticut \\ 06511, United States \\ ${ }^{\mathrm{b}}$ International Research Center for Renewable Energy, State Key Laboratory of Multiphase Flow in Power \\ Engineering, Xi'an Jiaotong University, Shanxi 710049, China \\ c Energy Sciences Institute, Yale University, West Haven, Connecticut 06516, United States \\ ${ }^{\mathrm{d}}$ National Renewable Energy Laboratory, Golden, Colorado 80401, United States

\section{Corresponding Author} \\ *Email: shu.hu@yale.edu \\ *Email: shshen_xjtu@mail.xjtu.edu.cn
}




\section{Experimental Methods}

\section{Preparation of CdS and CdTe Films}

The CdS/CdTe heterojunctions were synthesized according to the previous publication. ${ }^{1}$ The $\mathrm{CdS}$ window layer was first deposited by radio-frequency (RF) sputtering on a $\mathrm{SnO}_{2}: \mathrm{F} / \mathrm{SnO}_{2}$ transparent conducting oxide (TCO) layer at room temperature using a hot-pressed CdS target and then the $\mathrm{CdS}$ layer was annealed at $600{ }^{\circ} \mathrm{C}$ for $5 \mathrm{~min}$ in a $4 \% \mathrm{O}_{2}$-in-Ar mixture. A CdTe layer was grown on top of the CdS layer by using a close-spaced sublimation (CSS) method, with the source and substrate temperatures held at 660 and $600{ }^{\circ} \mathrm{C}$, respectively. Vapor-phase $\mathrm{CdCl}_{2}$ annealing was subsequently performed in a CSS configuration at $430{ }^{\circ} \mathrm{C}$ for $10 \mathrm{~min}$. Copper $(\mathrm{Cu})$ was introduced through a wet $0.1 \mathrm{mM} \mathrm{CuCl}_{2}(\mathrm{aq})$ solution treatment, followed by annealing.

For fabricating the CdS/CdTe solar cells, Au back contacts were coated by electron-beam evaporation at room temperature without intentional substrate heating. For the CdTe photoanode fabrication, a bromine/methanol etching treatment for CdTe was performed prior to coating $\mathrm{TiO}_{2}$ by atomic layer deposition (ALD). The CdTe sample was dipped in a freshly made bromine/methanol $(0.1 \%$ by volume ratio) solution for $30 \mathrm{~s}$, followed by rinsing with copious amounts of methanol and then dried in a stream of $\mathrm{N}_{2}$. An alternative $\mathrm{Ar}^{+}$sputtering surface treatment was tried, in which an ion gun was used to sputter-etch the sample surface with 500-eV $\mathrm{Ar}^{+}$ions for $5 \mathrm{~min}$.

\section{ALD $\mathrm{TiO}_{2}$ Stabilization Coating}

$\mathrm{TiO}_{2}$ stabilization layers were coated onto the $\mathrm{CdTe}\left(\mathrm{CdTe} / \mathrm{CdS} / \mathrm{SnO}_{2} / \mathrm{SnO}_{2}: \mathrm{F}\right.$ layered stack), $\mathrm{Si}$, and $\mathrm{SnO}_{2}: \mathrm{F}$ substrates at $150{ }^{\circ} \mathrm{C}$ using an Ultratech Fiji G2 ALD system. Both the Si and $\mathrm{SnO}_{2}: \mathrm{F}$ substrates were cleaned with deionized water, acetone, and ethanol in sequence and loaded immediately into the ALD chamber. Prior to ALD $\mathrm{TiO}_{2}$, the surface of CdTe in the CdS/CdTe films stack was prepared by bromine/methanol etching as described above. Each ALD cycle consisted of a $0.06 \mathrm{~s}$ pulse of $\mathrm{H}_{2} \mathrm{O}$, followed by a $0.25 \mathrm{~s}$ pulse of tetrakis-dimethylamido-titanium (TDMAT, Sigma-Aldrich, 99.999\%). A constant flow of Ar (99.9997\%) gas purged the reactor between each precursor pulse. $\mathrm{TiO}_{2}$ coatings of $\sim 110-\mathrm{nm}$ thickness were conformally deposited on the surfaces of the substrates, with the cycle number for the thickness calculated according to a planar growth rate of $0.47 \AA$ per cycle. ${ }^{2}$ 


\section{Deposition of $\mathrm{Ni} / \mathrm{NiO}_{\mathrm{x}}$ Films}

Ni metal films of $\sim 50-\mathrm{nm}$ thickness were deposited onto the surfaces of ALD $\mathrm{TiO}_{2}$ layers using a thermal evaporation system (MBraun, MB-EcoVap) with Ni pellets (Kurt J. Lesker Corp., $99.995 \%$ ) as the source material. The background pressure was kept at $1 \times 10^{-6} \mathrm{~Pa}$. The evaporation rate was controlled at a constant of $0.03 \mathrm{~nm} \mathrm{~s}^{-1}$. The $\mathrm{Ni}$ surfaces become $\mathrm{Ni} / \mathrm{NiO}_{\mathrm{x}}$ during PEC water oxidation, so we denote $\mathrm{Ni} / \mathrm{NiO}_{\mathrm{x}}$ as the OER electrocatalyst.

\section{Materials Characterizations}

X-ray diffraction (XRD, Rigaku SmartLab) was used to identify the crystal structure of the CdTe films after film growth and post-growth treatment. The XRD instrument employs a $\mathrm{Cu} \mathrm{K} \alpha$ source with a beam energy of $8.04 \mathrm{keV}$, which corresponds to an X-ray wavelength of $1.5406 \AA$. Optical absorption properties were measured using an Ultraviolet-visible (UV-vis) spectrophotometer (UV-2600, SHIMADZU) under a diffused reflectance spectroscopy (DRS) configuration. The light was incident from the TCO side and the light absorption of CdTe based photoanodes could be calculated by Absorption (\%) = 100\% - Reflection (\%) - Transmission (\%). To characterize the film morphology, scanning electron microscope (SEM) was performed using a Hitachi SU8230 UHR system. Energy dispersive X-ray spectroscopy (EDX, Bruker QUANTAX FlatQUAD) attached to this SEM system was conducted to observe the elemental distribution of the film. Xray photoelectron spectroscopy (XPS, PHI VersaProbeII) was used to investigate the elemental composition and the oxidation state of the as-prepared films. Steady-state photoluminescence (PL) measurements were performed using a Raman spectrometer (HORIBA Scientific) under room temperature. The excitation wavelength was set at $528 \mathrm{~nm}$ by using a tunable filter to pick the output light of 10-nm bandwidth from a supercontinuum laser (NKT photonics). A $570 \mathrm{~nm}$ longpass filter was used to filter and block the 528-nm excitation light. Time-resolved photoluminescence (TRPL) was acquired using time-correlated single-photon counting (PicoHarp 300), with a 528-nm pulsed laser for optical excitation and a monochromator set at a center wavelength of $840 \mathrm{~nm}$ for PL decay detection. The PL intensity decay was fit by a single exponential equation, and the decay time constant was obtained as an indicator for surface recombination. Microscope (OLYMPUS BX51) was used to obtain the dark field images to exam the morphology of $\mathrm{CdS} / \mathrm{CdTe} / \mathrm{TiO}_{2} / \mathrm{Ni} / \mathrm{NiO}_{\mathrm{x}}$ photoanodes after stability testing. 


\section{Photoelectrochemical (PEC) Performance Characterization}

All PEC measurements for CdTe photoanodes were conducted using a Bio-Logic S200 potentiostat in a three-electrode PEC cell, with the photoanode as the working electrode, a $\mathrm{Ag} / \mathrm{AgCl}$ electrode as the reference electrode, and a Pt wire as the counter electrode. A porous glass plate separates the working and the counter electrodes. The light source was produced from a Xe lamp (Newport, $300 \mathrm{~W}$ ) with an AM 1.5G filter. The illumination intensity was calibrated by placing a Si photodiode (FDS100, Thor Labs) in the electrolyte-containing electrochemical cell in the same location as the photoelectrode during PEC performance measurements.

For the PEC measurements, the electrolyte used was $1.0 \mathrm{M} \mathrm{KOH}(\mathrm{pH}=14)$. The applied bias vs $\mathrm{Ag} / \mathrm{AgCl}$ was converted into a reversible hydrogen electrode (RHE) according to the equation (1) below: ${ }^{3}$

$$
E_{R H E}=E_{A g / A g C l}+0.059 \times p H+0.1976
$$

The current density vs potential $(J-E)$ measurements, including cyclic voltammetry $(\mathrm{CV})$ and linear sweep voltammetry (LSV) were conducted with a scan rate of $20 \mathrm{mV} \mathrm{s}^{-1}$. The solution resistance loss was corrected according to equation $(2):^{4,5}$

$$
E_{\text {corr }}=E_{\text {meas }}-i R_{s}
$$

, where $R_{s}$ represents the solution resistance, which is extracted from impedance measurement.

During the stability test, the photocurrent vs time $(I-t)$ curve was recorded under a bias voltage of $2.0 \mathrm{~V}$ vs RHE, at which potential the photocurrent reached a light-limited value. Incident photon-to-current-efficiency (IPCE) measurements were performed under different wavelengths. The light source (at a 10-nm bandwidth and chopped at $27 \mathrm{~Hz}$ ) was generated from a computercontrolled monochromator (Newport Corp.). A chopping frequency of $27 \mathrm{~Hz}$ was reasonable considering that the response time constant was less than milliseconds for the CdTe photoelectrode if it is given a step potential. Monochromated light, obtained by passing through a long-pass filter to remove higher-order diffractions, was focused to a spot size that under-fill the photoelectrode active area. The incident light intensity at each wavelength was calibrated using a silicon photodiode (FDS100-CAL, Thor Labs) of known quantum yields. Therefore, the IPCE value could be calculated according to the following equation:

$$
I P C E=1240 \times \frac{J_{\lambda}}{\lambda P_{\lambda}}
$$

, where $J_{\lambda}$ is the photocurrent density $\left(\mathrm{mA} \mathrm{cm}^{-2}\right)$ under illumination of wavelength $\lambda(\mathrm{nm})$, and $P_{\lambda}$ is the power intensity of the incident monochromatic light. The applied potential was set at three 
increasing values of $1.5 \mathrm{~V}, 1.7 \mathrm{~V}$ and $2.0 \mathrm{~V}$ vs RHE, to make sure the full extraction of photogenerated carriers in the photoanode at $1.5 \mathrm{~V}$ vs RHE.

\section{Electrochemical Impedance Spectroscopy (EIS) Analysis}

To study the liquid interfacial energetics of $\mathrm{TiO}_{2}$-coated $\mathrm{CdTe}$ photoanodes immersed in aqueous electrolytes, Mott-Schottky differential capacitance-potential analysis was derived from EIS measurements. The measurements were conducted in an aqueous solution of $\mathrm{Fe}(\mathrm{CN})_{6}^{3-/ 4-}$ redox couple $\left[50 \mathrm{mM} \mathrm{K}_{3} \mathrm{Fe}(\mathrm{CN})_{6}\right.$ and $\left.350 \mathrm{mM} \mathrm{K}_{4} \mathrm{Fe}(\mathrm{CN})_{6}\right]$ in the complete dark. The frequency ranged from $5 \mathrm{MHz}$ to $1 \mathrm{~Hz}$ and the waiting time for each potential step was $5 \mathrm{~s}$. A $50-\mathrm{nm} \mathrm{TiO} 2$ layer was coated on $\mathrm{SnO}_{2}: \mathrm{F}$ for Mott-Schottky analysis. The differential capacitance of the space charge region was calculated by fitting the data with a Randles circuit in which a constant phase element (CPE) and a resistor in parallel were connected in series with another resistor.

The solution resistance $\left(\mathrm{R}_{\mathrm{s}}\right)$ was also obtained by EIS measurements in $1.0 \mathrm{M} \mathrm{KOH}(\mathrm{aq})$ in the dark. The $R_{s}$ value was extracted by fitting the data with a Randles circuit, in which the series resistance component was defined as $R_{s}$.

\section{Solid-State Electrical Measurements}

For both $\mathrm{CdS} / \mathrm{CdTe} / \mathrm{Ni} / \mathrm{NiO}_{\mathrm{x}}$ and $\mathrm{CdS} / \mathrm{CdTe} / \mathrm{Au}$ devices, the front and back electrical ohmic contacts were connected through the $\mathrm{SnO}_{2}: \mathrm{F} / \mathrm{SnO}_{2}$ and the $\mathrm{Ni} / \mathrm{NiO}_{\mathrm{x}}(\mathrm{Au})$ films, respectively. This device was held by a chip carrier, and the back electrical ohmic contact for the $\mathrm{CdS} / \mathrm{CdTe} / \mathrm{TiO}_{2} / \mathrm{Ni} / \mathrm{NiO}_{\mathrm{x}}(\mathrm{Au})$ structure was formed by bonding $\mathrm{Ni}(\mathrm{Au})$ contact pads with $\mathrm{Al}$ wires. Solid-state current vs voltage $(J-V)$ measurements were performed using a two-electrode setup, with the working electrode connected to $\mathrm{Ni} / \mathrm{NiO}_{\mathrm{x}}(\mathrm{Au})$, and with the counter and reference

electrodes shorted and electrically wired to In dots that are soldered onto $\mathrm{SnO}_{2}: \mathrm{F} / \mathrm{SnO}_{2}$. The illumination was calibrated to a simulated solar light (AM 1.5G, $100 \mathrm{~mW} \mathrm{~cm} \mathrm{~cm}^{-2}$ ). 


\section{Supplementary Discussions}

\section{Structural Characterizations of $\mathrm{CdS} / \mathrm{CdTe} / \mathrm{TiO}_{2} / \mathrm{Ni} / \mathrm{NiO}_{\mathbf{x}}$ Multilayers}

SEM images showed that the CdS polycrystalline film with a thickness of $100 \mathrm{~nm}$ was uniformly coated on the TCO layer. No diffraction peaks from this CdS window layer were observed obviously due to its thickness as thin as $100 \mathrm{~nm}$. Instead, CdS was detected by SEM and EDX mapping. A $\sim 3.5-\mu \mathrm{m}$ thick CdTe film was densely grown on the top of CdS (Figure S2, Figure S3a). The small crystallites (100 nm in size) that existed at the grain boundaries of CdTe were produced during annealing in a $\mathrm{CdCl}_{2}$ atmosphere, which was designed to eliminate the boundary defects or pinhole defects of CdTe. ${ }^{6}$ It will be elucidated later that the post-growth $\mathrm{CdCl}_{2}$ annealing procedure further improved CdTe density, thereby reducing pinhole density and enhancing stability. The CdS/CdTe films were then conformally coated with 110-nm thick ALDgrown $\mathrm{TiO}_{2}$, followed by $\sim 50 \mathrm{~nm}$ thermal evaporated $\mathrm{Ni} / \mathrm{NiO}_{\mathrm{x}}$ (Figure $\mathbf{S 3 b}$, Figure S3c and Figure S4). Only $\mathrm{Ni}$ element present in combination of $\mathrm{Ni} / \mathrm{NiO}_{\mathrm{x}}$ was detected by investigating the XPS spectra (Figure S5), further confirming that the uniform $\mathrm{TiO}_{2} / \mathrm{Ni} / \mathrm{NiO}_{\mathrm{x}}$ coatings fully covered the top of $\mathrm{CdS} / \mathrm{CdTe}$ structure. ${ }^{7,8}$

\section{Oxidation State of p-Type CdTe Surface}

XPS measurements were performed to characterize the Te oxidation state of p-type CdTe surfaces. The Multipak software was used to quantify the surface elemental composition of CdTe. As shown in Figure S10, the atom concentrations of C, O, Cd, and Te were 57.39\%, 21.54\%, $11.80 \%$ and $9.29 \%$, respectively. Note that except for CdTe compounds, there were also surface tellurium oxides, which would seriously inhibit the charge transfer at the interface as a tunnel barrier. The tellurium oxide would also cause the recombination of photogenerated carriers, thus

leading to a low photovoltage. ${ }^{9}$ After $\mathrm{Ar}^{+}$sputter-etching treatment for $\mathrm{CdTe}, \mathrm{C}$ was completely removed. The atomic composition ratio of $\mathrm{O}, \mathrm{Cd}$, and Te was 0.22 to 1.21 to 1 , revealing that the surface oxidation layer was effectively removed (Figure S11). Additionally, bromine/methanol ( $0.1 \%$ by volume ratio) etching of $\mathrm{CdTe}$ for $30 \mathrm{~s}$ not only removed the tellurium oxidation layer, but also created a Te-rich surface (atomic ratio of $\mathrm{Cd}$ to $\mathrm{Te}=0.73: 1$ ) according to the previous publication. ${ }^{10}$ It has been reported that the formation of small valence band offset between CdTe and Te could facilitate photogenerated holes transfer from CdTe to Te layer. ${ }^{11,12}$ 


\section{Band-Edge Energetics Determination by Mott-Schottky Analysis}

According to Mott-Schottky analysis, the inverse square of the differential capacitance $\left(\mathrm{C}^{-2}\right) \mathrm{vs}$ potential ( $E$ vs RHE) was plotted for the $\mathrm{SnO}_{2}: \mathrm{F} / \mathrm{TiO}_{2}$ electrode. The flat-band potential, which is the Fermi level $\left(\mathrm{E}_{\mathrm{f}}\right)$ with respect to the solution when the electronic bands of $\mathrm{TiO}_{2}$ become flat across the film-thickness direction, could be represented by a linear fit of $C^{-2} \mathrm{vs} E .^{13}$

According to Figure S15, we obtained the space charge density by the following equation: ${ }^{14}$

$$
\frac{1}{C^{2}}=\frac{2}{\varepsilon \varepsilon_{0} q N_{D}}\left(E-E_{F B}-\frac{k T}{q}\right)
$$

where $C$ represents the differential capacitance; $\varepsilon(=130)$ is the dielectric constant of $\mathrm{TiO}_{2} ; \varepsilon_{0}$ is the vacuum dielectric constant $\left(8.854 \times 10^{-14} \mathrm{~F} \mathrm{~cm}^{-1}\right) ; q$ is the absolute charge of an electron; $N_{D}$ is the space charge density (in typical semiconductors, it means the doping concentration because the semiconductor is depleted with ); $E$ is the applied potential; $E_{F B}$ is the flat band potential; $k$ is the Boltzmann constant; and $T$ is the temperature.

Conventionally, $N_{D}$, the space charge density, is used to approximate the free carrier concentration, but it is not true for intermediate-band oxides. According to a slope of $5.1 \times 10^{9} \mathrm{~F}^{-2}$ $\mathrm{cm}^{4} \mathrm{~V}^{-1}$ for the Mott-Schottky plot, the fixed positive space charge density of this ALD $\mathrm{TiO}_{2}$ was calculated to be $2.1 \times 10^{20} \mathrm{~cm}^{-3}$. Typically, the space charge density equals to the doping density and free carrier concentration. However, the free carrier concentration, in "leaky" $\mathrm{TiO}_{2}$, should not equal to the space charge density, which is due to oxygen vacancy. The spatial density of electron trap states due to $\mathrm{Ti}^{3+}$ defects is also on the order of $10^{20} \mathrm{~cm}^{-3}$. Therefore, it is considered that the free carriers are trapped, resulting in a unique observation of a high space charge density and a low free carrier concentration. The respective $\mathrm{E}_{\mathrm{f}}$ is lowered to the $\mathrm{Ti}^{3+}$-defect band edge, $0.4 \mathrm{eV}$ below the $\mathrm{TiO}_{2}$ conduction band $(\mathrm{CB})$ edge. The $\mathrm{E}_{\mathrm{f}}$ value for $\mathrm{SnO}_{2}: \mathrm{F} / \mathrm{TiO}_{2}$ was $-0.8 \mathrm{~V}$ vs $\mathrm{Ag} / \mathrm{AgCl}$ in $\mathrm{Fe}(\mathrm{CN}) 6^{3-/ 4-}$ (pH 8.5). Valence band (VB) XPS data in our previous study showed a valence band maximum (VBM) of $2.94 \mathrm{eV}$ below the $\mathrm{E}_{\mathrm{f}}$ for this "leaky" $\mathrm{TiO}_{2}$. Therefore, the VBM position was $2.14 \mathrm{~V}$ vs $\mathrm{Ag} / \mathrm{AgCl}$ in water. According to the bandgap of $3.34 \mathrm{eV}$ for $\mathrm{TiO}_{2}$, the $\mathrm{CB}$ position lies at $-1.2 \mathrm{~V}$ vs Ag/AgCl. The position of the defect band for $\mathrm{TiO}_{2}$, with a density-of-state maximum at $0.94 \mathrm{eV} \pm 0.03 \mathrm{eV}$ below the $\mathrm{E}_{\mathrm{f}}$ and a full width at half-maximum (FWHM) of $0.88 \mathrm{eV} \pm 0.10$ $\mathrm{eV}$, was calculated to locate at the range of $-0.30 \mathrm{~V}-+0.58 \mathrm{~V}$ vs $\mathrm{Ag} / \mathrm{AgCl}{ }^{15}$

Many publications have reported the band alignment between $\mathrm{TiO}_{2}$ and CdTe. ${ }^{16-21}$ They can form a type-II staggered band structure for charge separation and transfer according to the $\mathrm{E}_{\mathrm{f}}$ 
alignment. For example, K. Ernst et al. reported that the CdTe CB lies approximately $0.6 \mathrm{eV}$ above the $\mathrm{TiO}_{2}$ conduction band. ${ }^{16-18}$ Tiefenbacher et al. demonstrated a $\mathrm{CB}$ offset of $0.7 \mathrm{eV}$ at the $\mathrm{CdTe} / \mathrm{TiO}_{2}$ interface. ${ }^{19}$ Brus et al. also reported an experimental $\mathrm{CB}$ discontinuity $\left(\Delta \mathrm{E}_{\mathrm{c}}\right)$ value of $0.7 \mathrm{eV}{ }^{20,21}$ Considering that our similar surface preparation and carrier concentration of $\mathrm{CdTe}$ with that reported by Brus et al., herein we adopted a CB offset of $0.7 \mathrm{eV}$. Then CdTe, with a bandgap of $1.5 \mathrm{eV}$, exhibits the $\mathrm{CB}$ and $\mathrm{VB}$ positions at $-1.9 \mathrm{~V}$ vs $\mathrm{Ag} / \mathrm{AgCl}$ and $-0.4 \mathrm{~V}$ vs $\mathrm{Ag} / \mathrm{AgCl}$, respectively. These values are shown in Figure 3 for the band alignment near the $\mathrm{CdTe} / \mathrm{TiO}_{2}$ interface. Therefore, the CdTe VBM of $-0.4 \mathrm{~V}$ vs $\mathrm{Ag} / \mathrm{AgCl}$ aligns with the $\mathrm{TiO}_{2}$ intermediate band of $-0.3 \mathrm{~V}-+0.58 \mathrm{~V}$ vs $\mathrm{Ag} / \mathrm{AgCl}(\mathrm{FWHM})$. This alignment explains the ohmic electrical conduction from CdTe VB to the $\mathrm{Ni} / \mathrm{NiO}_{\mathrm{x}}$ electrocatalysts through the $\mathrm{Ti}^{3+}$-defect band. ${ }^{15} \mathrm{Still}$, the interfacial layer and chemical property at the $\mathrm{CdTe} / \mathrm{TiO}_{2}$ interface have not yet been dertermined as cautiously represented with a dashed box, and the interfacial band energetics may not be flat.

We derive that the VBM of p-type CdTe aligned well with the intermediate band of "leaky" $\mathrm{TiO}_{2}$, indicating a low resistance contact, which favors the interfacial charge transport. It is known that the band alignment at the interface of two semiconductors is affected by the $\mathrm{E}_{\mathrm{f}}$, doping concentration, interfacial reaction, surface states, etc. ${ }^{22}$ Therefore, it is reasonable that two semiconductors could generate different band alignments. For example, Tiefenbacher et al. reported a VB offset of $2.6 \mathrm{eV}$, a $\mathrm{CB}$ offset of $0.7 \mathrm{eV}$ at the $\mathrm{CdTe} / \mathrm{TiO}_{2}$ interface. ${ }^{20}$ In their study, the $\mathrm{TiO}_{2} / \mathrm{CdTe}$ heterointerfaces were prepared inside the ultrahigh vacuum (UHV) chamber which avoids most detrimental cleaning procedures. The $\mathrm{TiO}_{2}$ film is heavily n-type doped and CdTe is weakly p-doped, with a $\mathrm{E}_{\mathrm{f}}$ of $0.5 \mathrm{eV}$ above the VBM. K. Ernst et al. also reported a $\mathrm{TiO}_{2} / \mathrm{CdTe}$ heterojunction, in which the $\mathrm{TiO}_{2} \mathrm{CB}$ locates at about the mid-gap of CdTe. ${ }^{16,17}$ Additionally, the Type II CdTe/ $/ \mathrm{TiO}_{2}$ heterojunctions as those observed in this study were reported. ${ }^{23,24}$

\section{Long-Term Stress Testing and Corrosion Analysis}

The $\mathrm{CdS} / \mathrm{CdTe} / \mathrm{TiO}_{2} / \mathrm{Ni} / \mathrm{NiO}_{\mathrm{x}}$ photoanodes were tested under $100 \mathrm{~mW} \mathrm{~cm}{ }^{-2}$ simulated solar illumination with the potential of the $\mathrm{SnO}_{2}: \mathrm{F} \mathrm{TCO}$ layer held constant at $2.0 \mathrm{~V}$ vs. RHE. During the long-term stress testing, the instability of the $\mathrm{CdS} / \mathrm{CdTe} / \mathrm{TiO}_{2} / \mathrm{Ni} / \mathrm{NiO}_{\mathrm{x}}$ photoanode mainly arises from CdS. Bright spots in dark-field optical images showed the corroded CdS pits that scattered light strongly (Figure S16). Accordingly, the photocurrent eventually decreased to $35 \%$ of the original photocurrent level (Figure S17) due to the weak points in CdS layers (Figure S16). 
In an extreme case of 350-hour stability testing, a portion of $\mathrm{TiO}_{2}$ coatings got lifted-off, thereby exposing the CdTe underneath the $\mathrm{TiO}_{2}$ coating (Figure S18), leading to accelerated CdTe photocorrosion and passivation. Plan-view SEM images indicated that the corroded CdTe crystallites, i.e., $\mathrm{CdTeO}_{\mathrm{x}}$, were re-deposited onto the electrode surface (Figure S19), and the corresponding EDX element mappings (Figure S20) also supported the re-deposition of $\mathrm{CdTeO}_{\mathrm{x}}$ particles. These results indicated the corrosion of both CdS and CdTe layers. But the CdS layers that are covered underneath the CdTe layers took more severe corrosion, and became the weak point of the CdTe photoanodes. XPS analysis revealed that the $\mathrm{Ni}$ element presents in $\mathrm{Ni}(\mathrm{OH})_{2}$, and the $\mathrm{Cd}$ and $\mathrm{Te}$ elements were also observed and found to exist at their highest oxidation state, i.e., $\mathrm{Cd}(\mathrm{II})$ and Te(IV), respectively (Figure S21). 


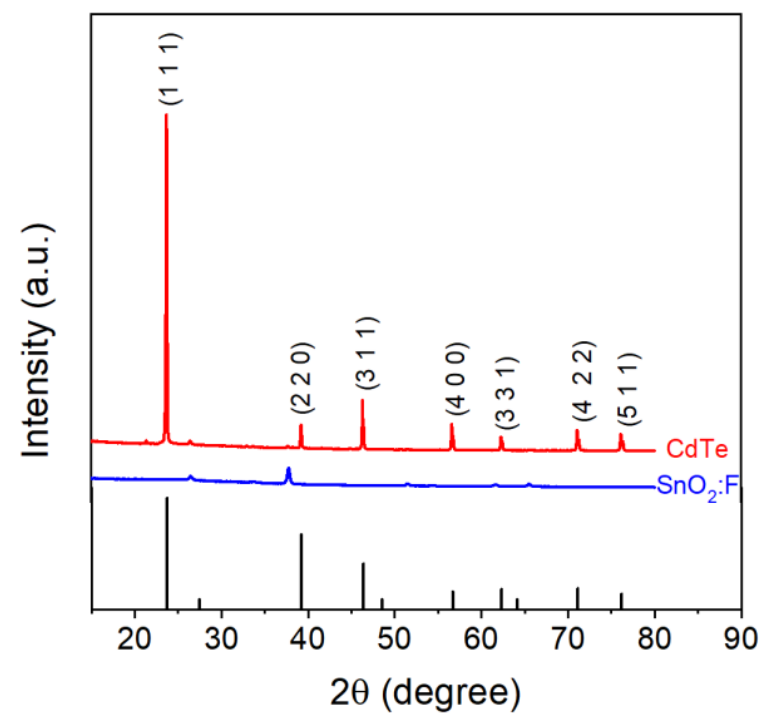

Figure S1. XRD patterns of the as-prepared CdS/CdTe layers, in which the CdTe film exhibited a cubic zincblend structure and a strong preferred orientation along the $\{111\}$-type planes. The $\mathrm{CdS}$ diffraction peaks were not detected obviously because it was too thin ( 110-nm thick).

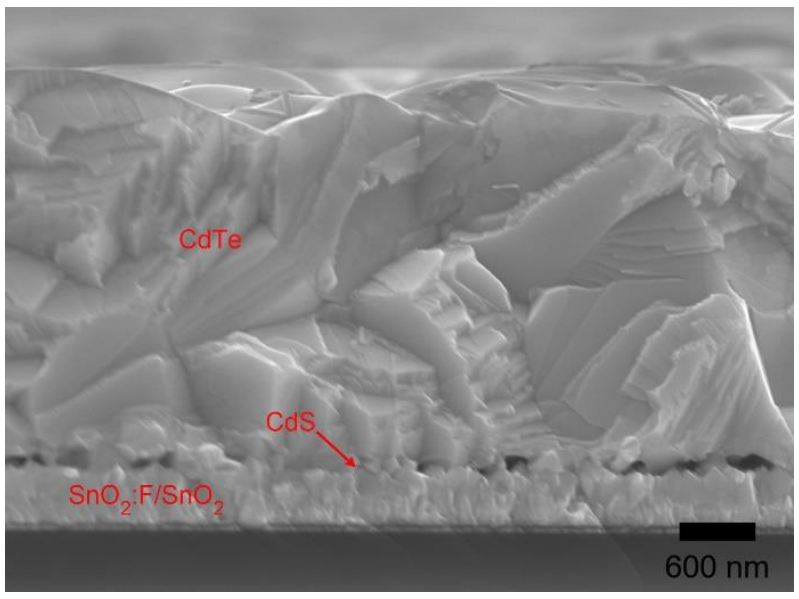

Figure S2. Cross-sectional SEM image of as-prepared CdS/CdTe films.
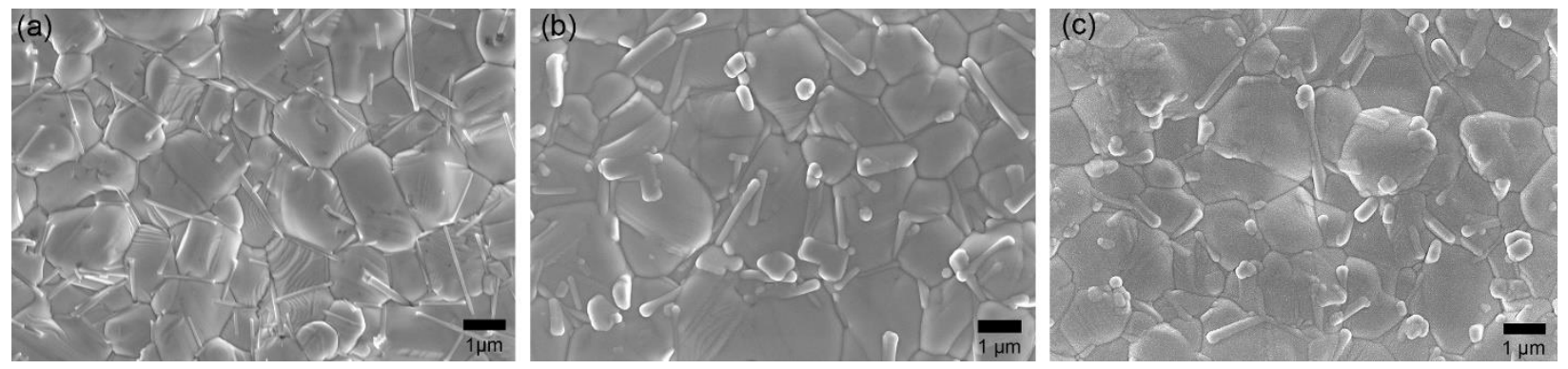

Figure S3. Plane-view SEM images of (a) $\mathrm{CdS} / \mathrm{CdTe}$, (b) $\mathrm{CdS} / \mathrm{CdTe} / \mathrm{TiO}_{2}\left(110 \mathrm{~nm}\right.$ ) and (c) $\mathrm{CdS} / \mathrm{CdTe} / \mathrm{TiO}_{2}$ $(110 \mathrm{~nm}) / \mathrm{Ni} / \mathrm{NiO}_{\mathrm{x}}(50 \mathrm{~nm})$ multilayer stacks. 


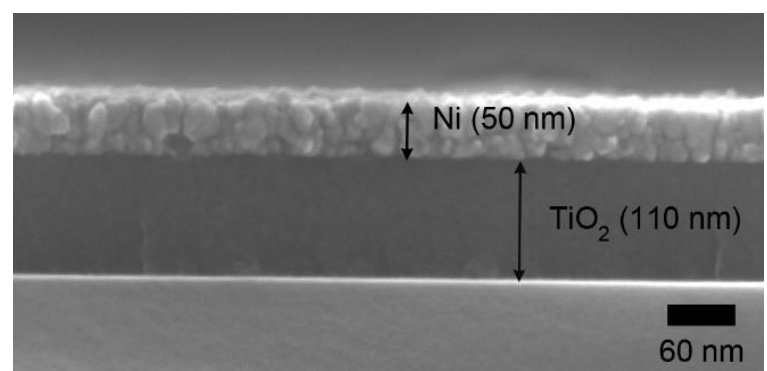

Figure S4. Cross-sectional SEM image of $\mathrm{Si} / \mathrm{TiO}_{2} / \mathrm{Ni} / \mathrm{NiO}_{\mathrm{x}}$, with the same growth parameters of $\mathrm{TiO}_{2}$ and $\mathrm{Ni} / \mathrm{NiO}_{\mathrm{x}}$ as CdS/CdTe. Herein, the ALD cycles of $\mathrm{TiO}_{2}$ was kept 2200 and the growth rate of $\mathrm{TiO}_{2}$ film was about $0.5 \AA$ A per cycle.
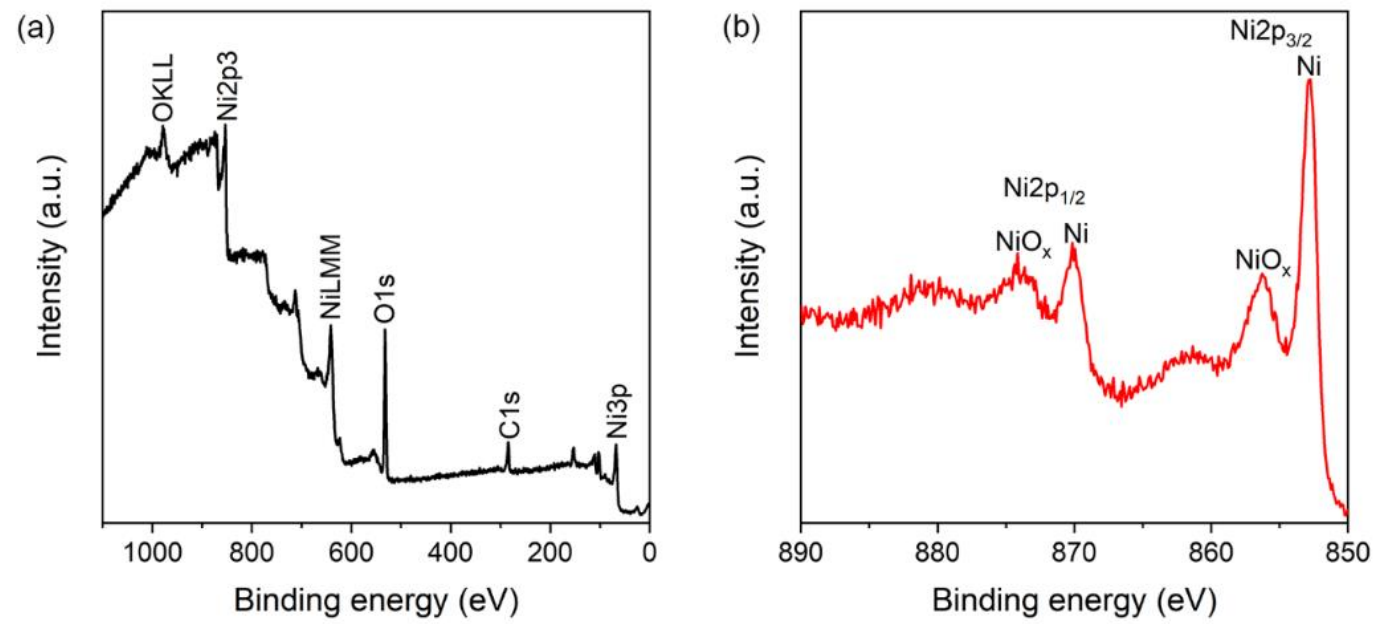

Figure S5. (a) XPS survey scan of $\mathrm{CdS} / \mathrm{CdTe} / \mathrm{TiO}_{2} / \mathrm{Ni} / \mathrm{NiO}_{\mathrm{x}}$ film. Neither $\mathrm{Cd}$ nor $\mathrm{Te}$ signal was detected, suggesting that the $\mathrm{TiO}_{2} / \mathrm{Ni} / \mathrm{NiO}_{\mathrm{x}}$ species have covered the CdTe surface completely. (b) Core-level XPS spectra of $\mathrm{Ni} 2 \mathrm{p}$ peaks, consisting of metallic $\mathrm{Ni}$ and $\mathrm{NiO}_{x}$.
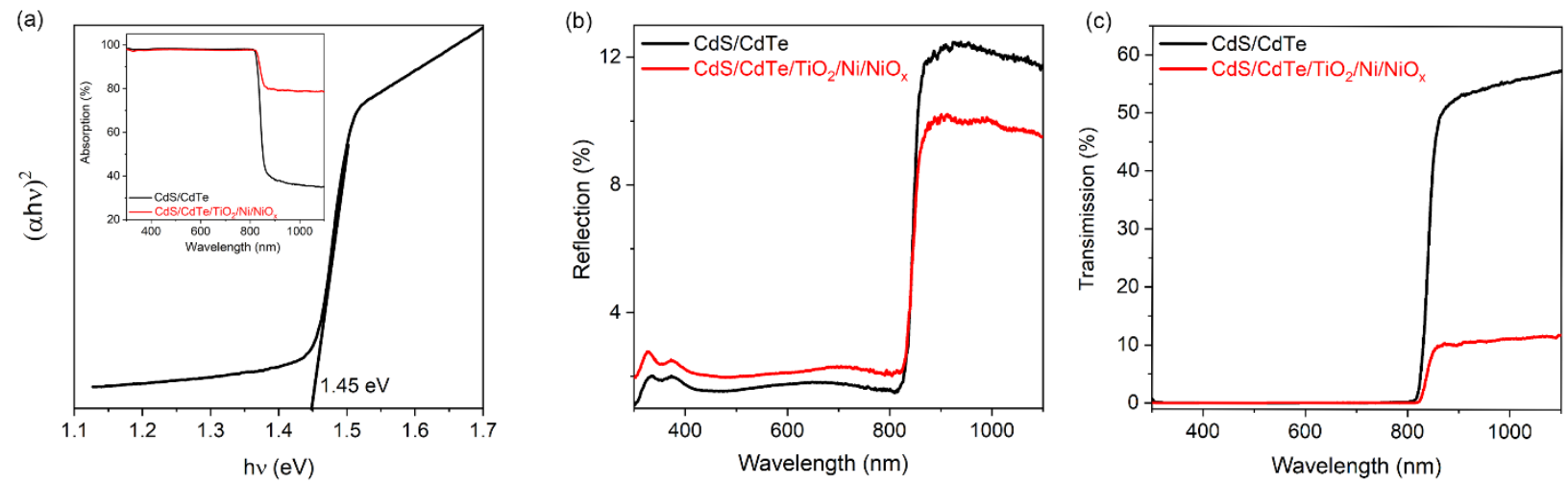

Figure S6. (a) Tauc plot of the CdS/CdTe layers acquired from its UV-vis DRS absorption property (black line in the inset). The band gap of CdTe was calculated to be $\sim 1.45 \mathrm{eV}$. The absorption property curve of the $\mathrm{CdS} / \mathrm{CdTe} / \mathrm{TiO}_{2} / \mathrm{Ni} / \mathrm{NiO}_{\mathrm{x}}$ film was also shown in the inset (red line). The improved light absorption at wavelength $>850 \mathrm{~nm}$ with Ni metallic back contacts was due to increased light scattering, which was supported by the reduced reflected (b) and transmitted (c) light. 


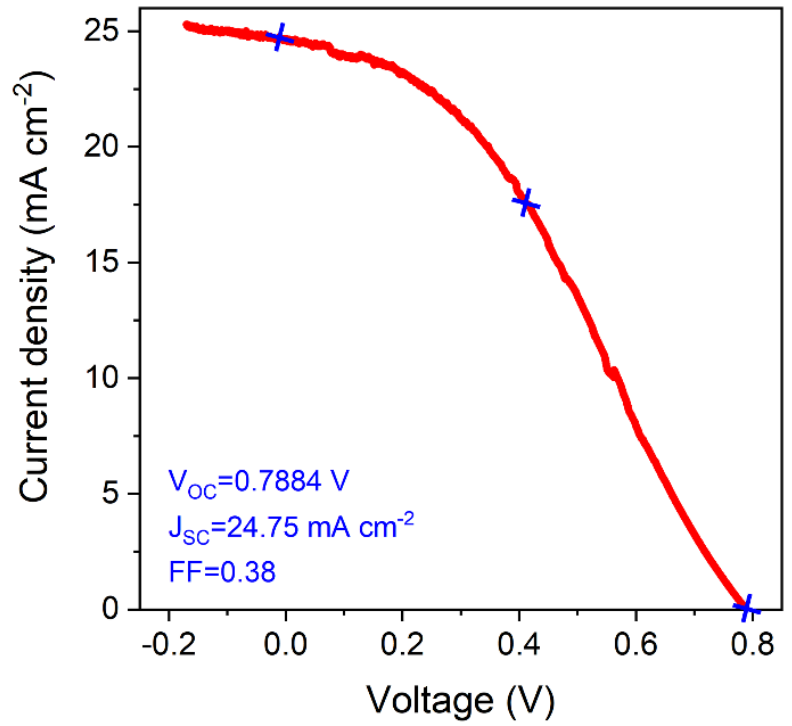

Figure S7. Solid-state $J-V$ curve of the $\mathrm{CdS} / \mathrm{CdTe} / \mathrm{TiO}_{2} / \mathrm{Ni} / \mathrm{NiO}_{\mathrm{x}}$ device under simulated 1-sun illumination, in which the open-circuit voltage $\left(\mathrm{V}_{\mathrm{oc}}\right)$ was $780 \pm 20 \mathrm{mV}$ and the short-circuit photocurrent density $\left(\mathrm{J}_{\mathrm{sc}}\right)$ was $24.5 \pm 0.5 \mathrm{~mA} \mathrm{~cm}^{-2}$.

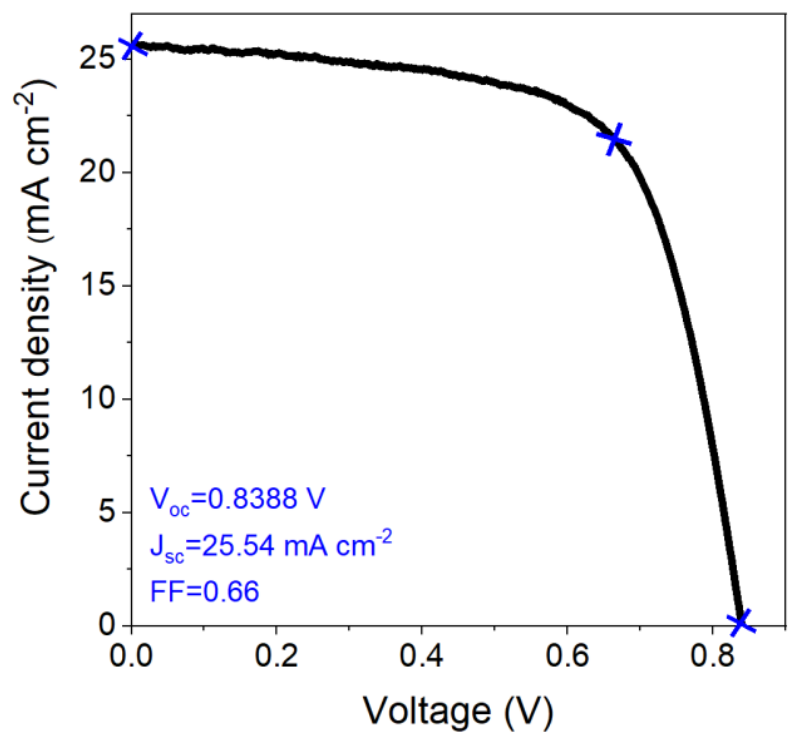

Figure S8. Solid-state $J-V$ curve of the CdTe solar cell $(\mathrm{CdS} / \mathrm{CdTe} / \mathrm{Au})$ under simulated 1-sun illumination, in which the $\mathrm{V}_{\mathrm{oc}}$ was $830 \pm 10 \mathrm{mV}$ and the $\mathrm{J}_{\mathrm{sc}}$ was $25.5 \pm 0.1 \mathrm{~mA} \mathrm{~cm}^{-2}$. 

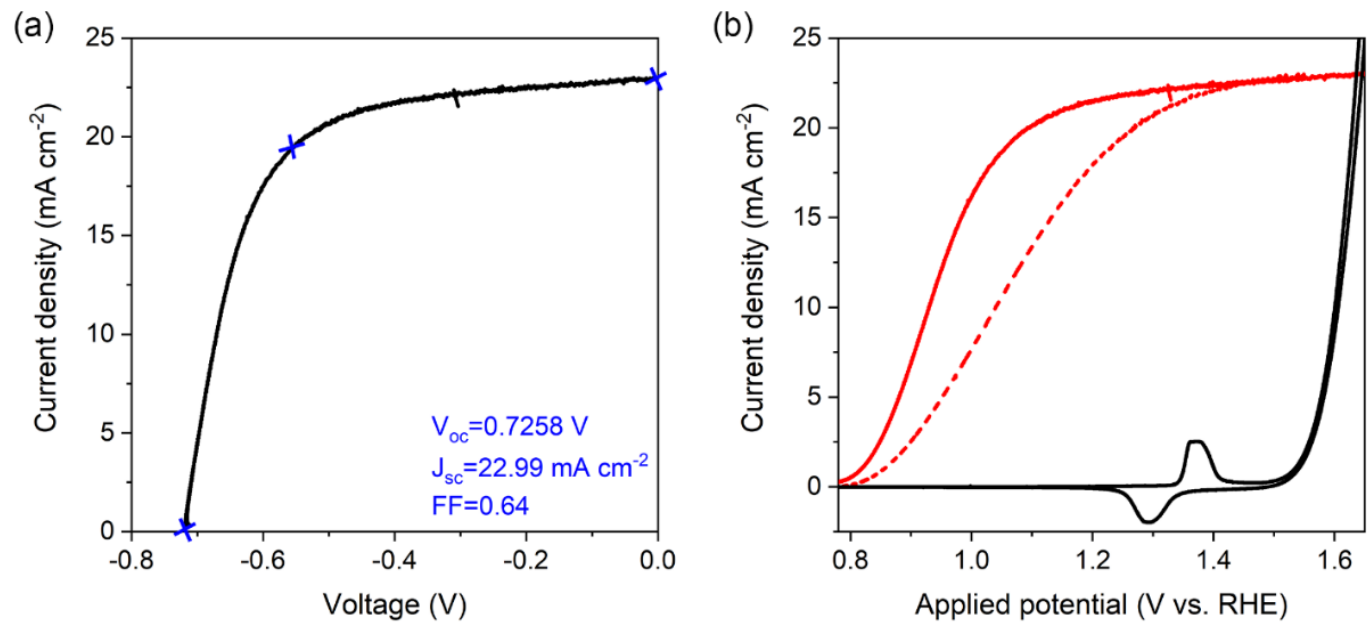

Figure S9. Intrinsic energy-conversion property of the $\mathrm{CdS} / \mathrm{CdTe} / \mathrm{TiO}_{2} / \mathrm{Ni} / \mathrm{NiO}_{\text {x }}$ photoanode. (a) Effective $I-V$ energy-conversion behavior of the CdTe photoanode by comparing the photoanode behavior with a dark $\mathrm{SnO}_{2}: \mathrm{F} / \mathrm{TiO} / \mathrm{Ni} / \mathrm{NiO}_{\mathrm{x}}$ anode using the same $\mathrm{Ni} / \mathrm{NiO}_{\mathrm{x}}$ catalysts, and (b) the measured $J-E$ characteristics of $\mathrm{CdS} / \mathrm{CdTe} / \mathrm{TiO}_{2} / \mathrm{Ni} / \mathrm{NiO}_{\mathrm{x}}$ photoanode before (dashed red line) and after (solid red line) correction for solution series resistance losses, and the electrocatalytic behavior of $\mathrm{a} \mathrm{SnO}_{2}: \mathrm{F} / \mathrm{TiO}_{2} / \mathrm{Ni} / \mathrm{NiO}_{\mathrm{x}}$ anode (solid black line). The $\mathrm{R}_{\mathrm{s}}$ value was calculated to be $12 \pm 1 \mathrm{ohm}$ according to the EIS analysis. 

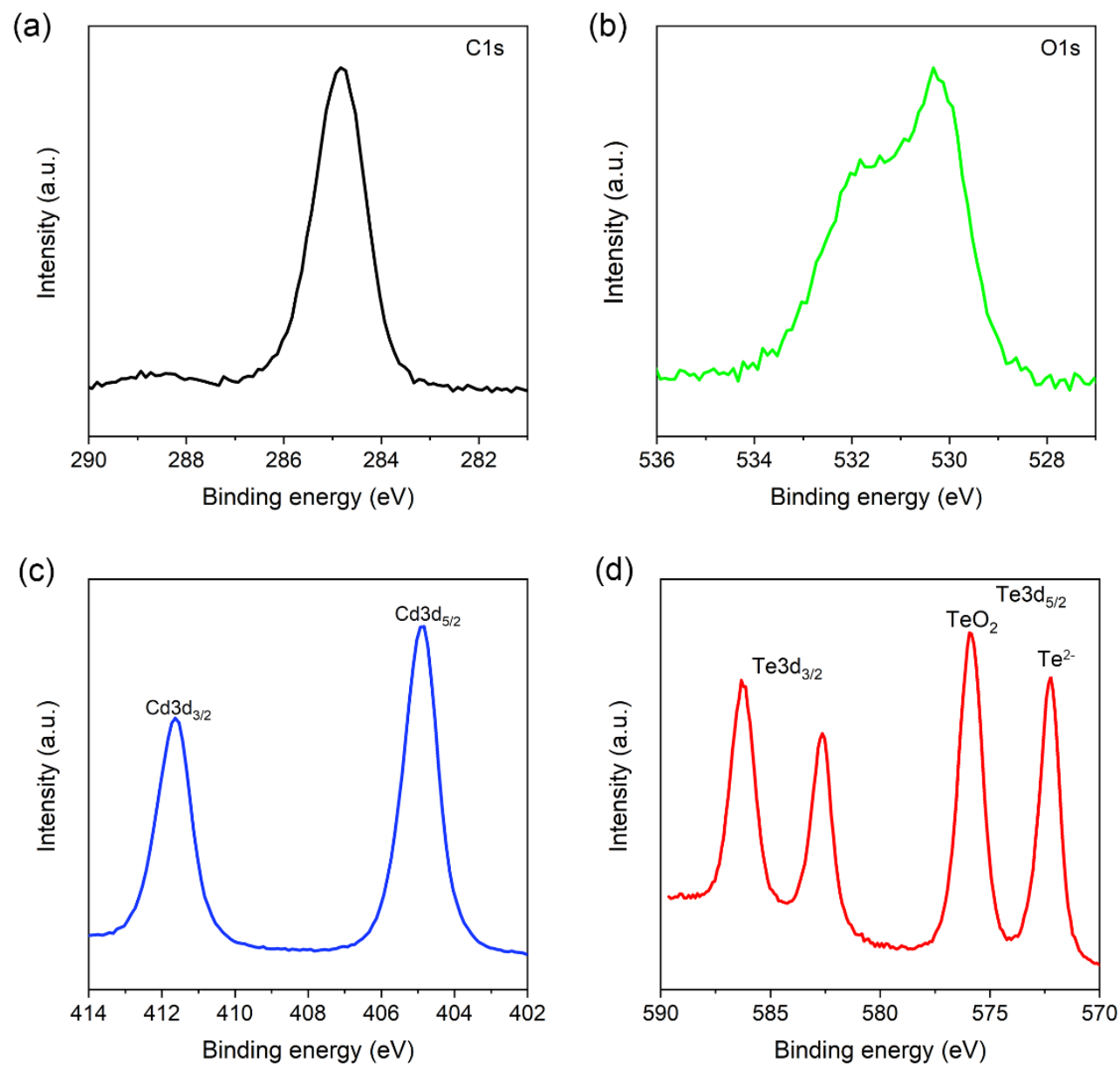

Figure S10. XPS spectra of element (a) C, (b) O, (c) Cd and (d) Te for as-prepared CdS/CdTe films. 

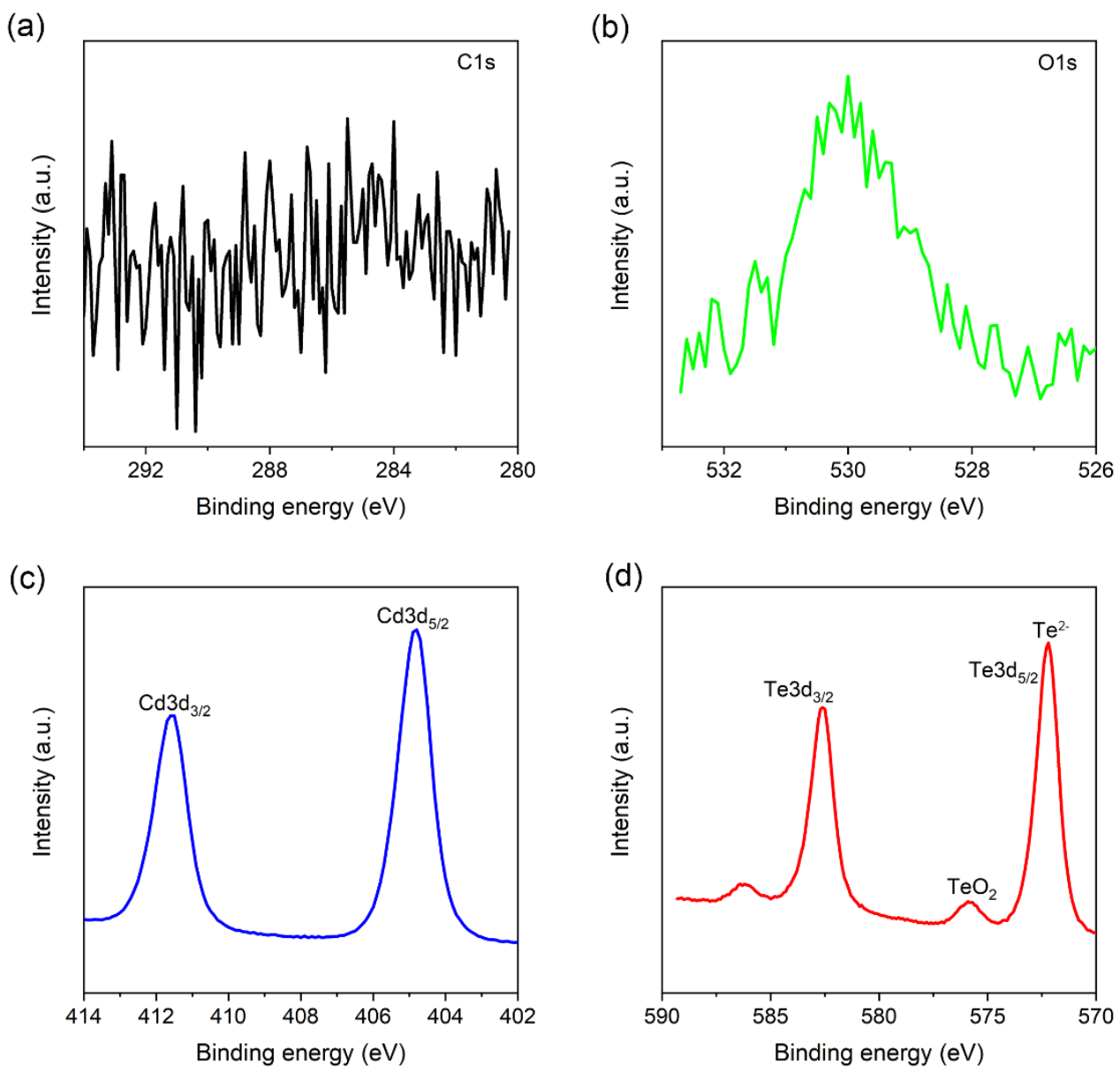

Figure S11. XPS spectra of element (a) C, (b) O, (c) Cd and (d) Te for CdTe after $\mathrm{Ar}^{+}$sputter-etching.

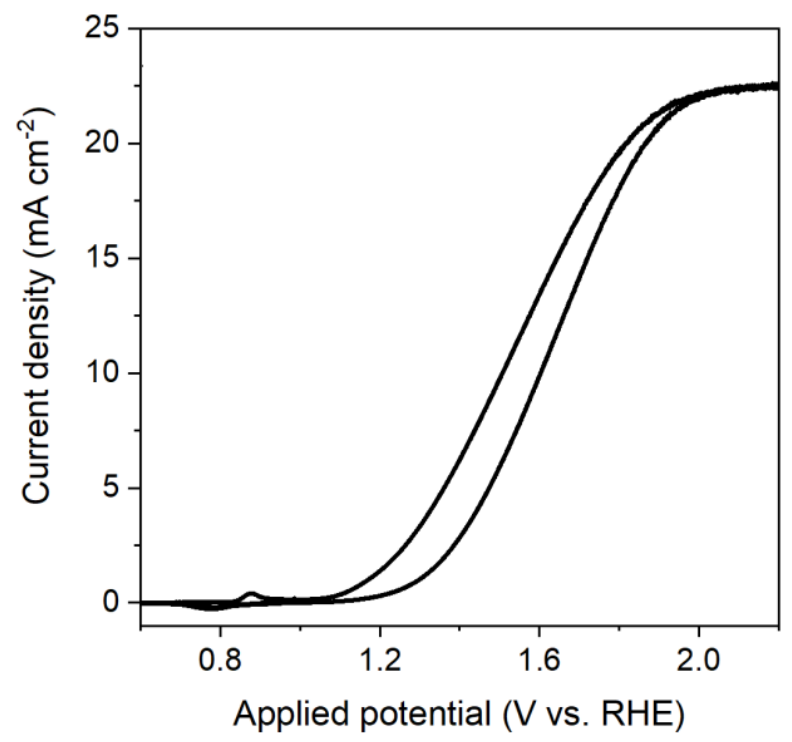

Figure $\mathrm{S} 12 . J-E$ behavior of $\mathrm{CdS} / \mathrm{CdTe} / \mathrm{TiO}_{2} / \mathrm{Ni} / \mathrm{NiO}_{\mathrm{x}}$ photoanode in $1.0 \mathrm{M} \mathrm{KOH}$ under illumination. CdTe was etched by $\mathrm{Ar}^{+}$sputter prior to deposition of $\mathrm{TiO}_{2}$. It was noted that the onset potential was $\sim 1.03 \mathrm{~V}$ vs RHE . 


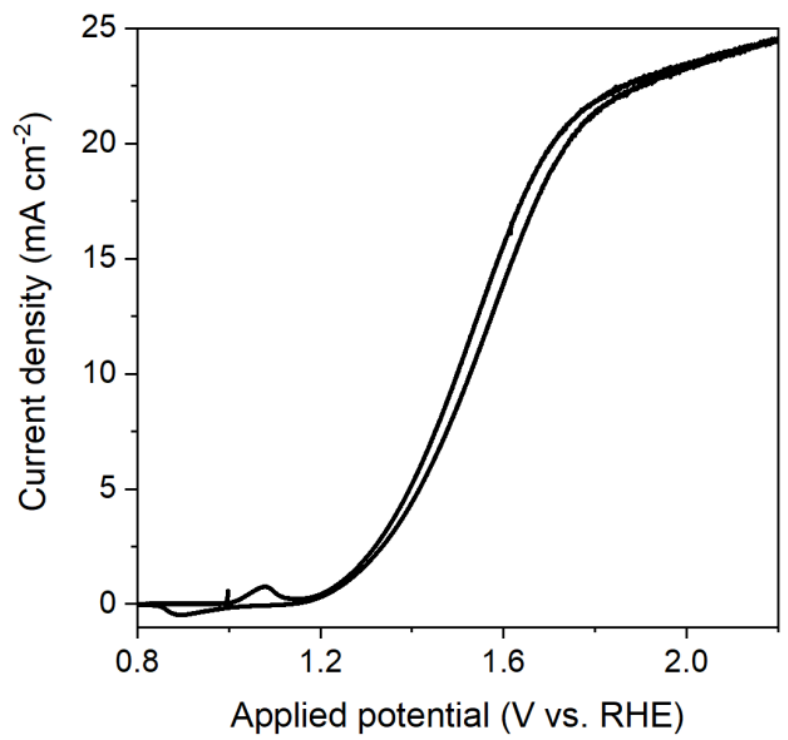

Figure $\mathrm{S} 13 . J-E$ behavior of $\mathrm{CdS} / \mathrm{CdTe} / \mathrm{TiO}_{2} / \mathrm{Ni} / \mathrm{NiO}_{x}$ photoanode in $1.0 \mathrm{M} \mathrm{KOH}$ under illumination. $\mathrm{CdTe}$ was coated by $\mathrm{TiO}_{2}$ directly without any etching treatment beyond cleaning with $\mathrm{CH}_{3} \mathrm{OH}$. The onset potential was $\sim 1.18 \mathrm{~V}$ vs RHE.

(a)

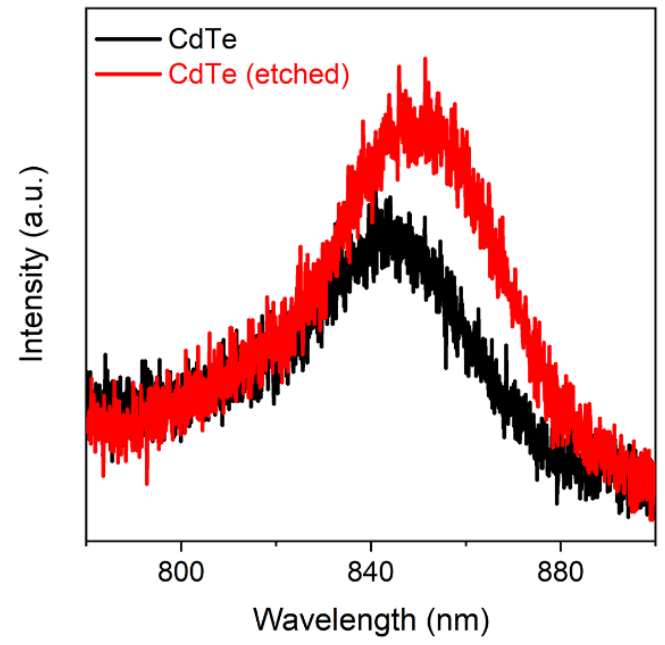

(b)

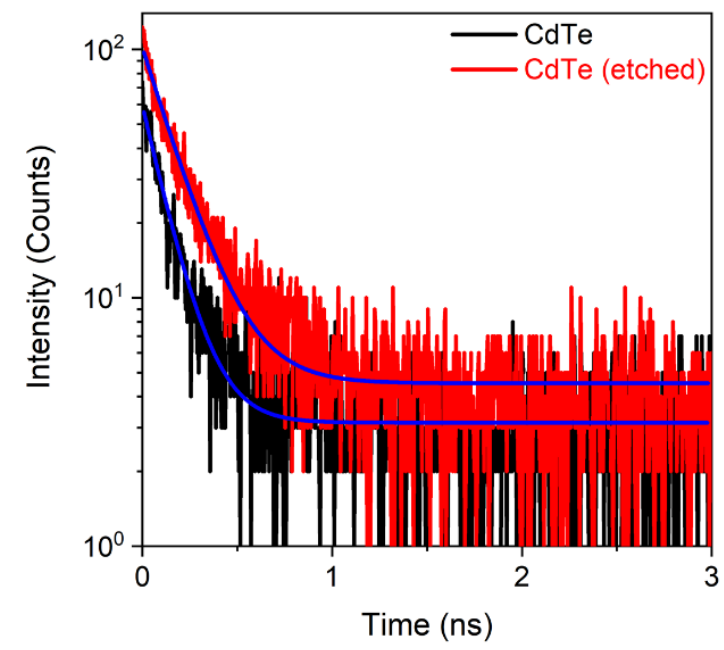

Figure S14. (a) Steady-state PL spectra of CdTe films before and after bromine/methanol etching treatment and (b) the corresponding TRPL measurements. Herein, single exponential data analysis model $\left(y=y_{0}+A e^{\frac{-t}{\tau}}\right)$ was adopted to fit the PL decay. The calculated $\tau$ values for the CdTe films before and after etching treatment were $127 \mathrm{ps}$ and $171 \mathrm{ps}$, respectively, indicating that surface etched by bromine/methanol made a modest improvement to the minority carrier lifetime of CdTe. 


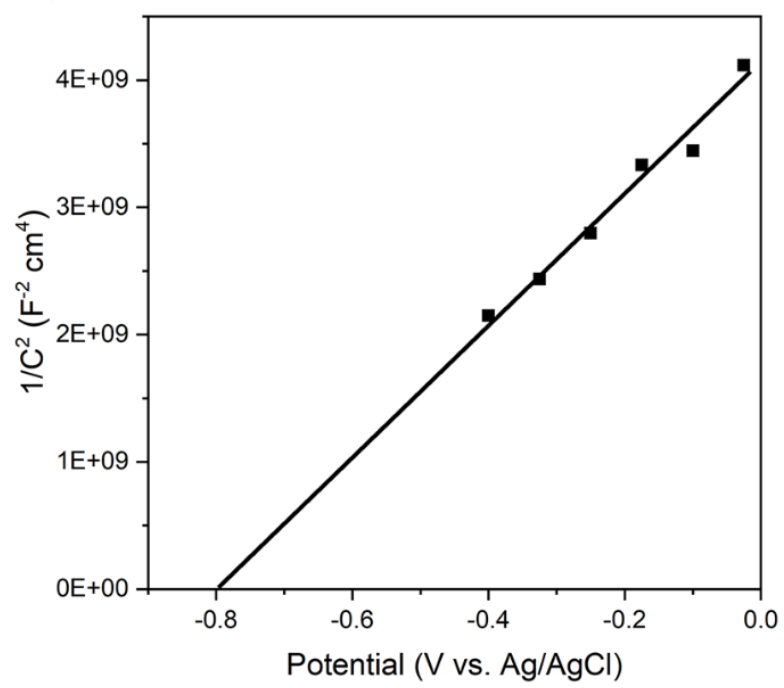

Figure S15. Mott-Schottky analysis of the $\mathrm{SnO}_{2}: \mathrm{F} / \mathrm{TiO}_{2}$ electrode. Electrolyte: $\mathrm{Fe}(\mathrm{CN})_{6}{ }^{3-14-}$ redox couple $(\mathrm{pH}$ 8.5).
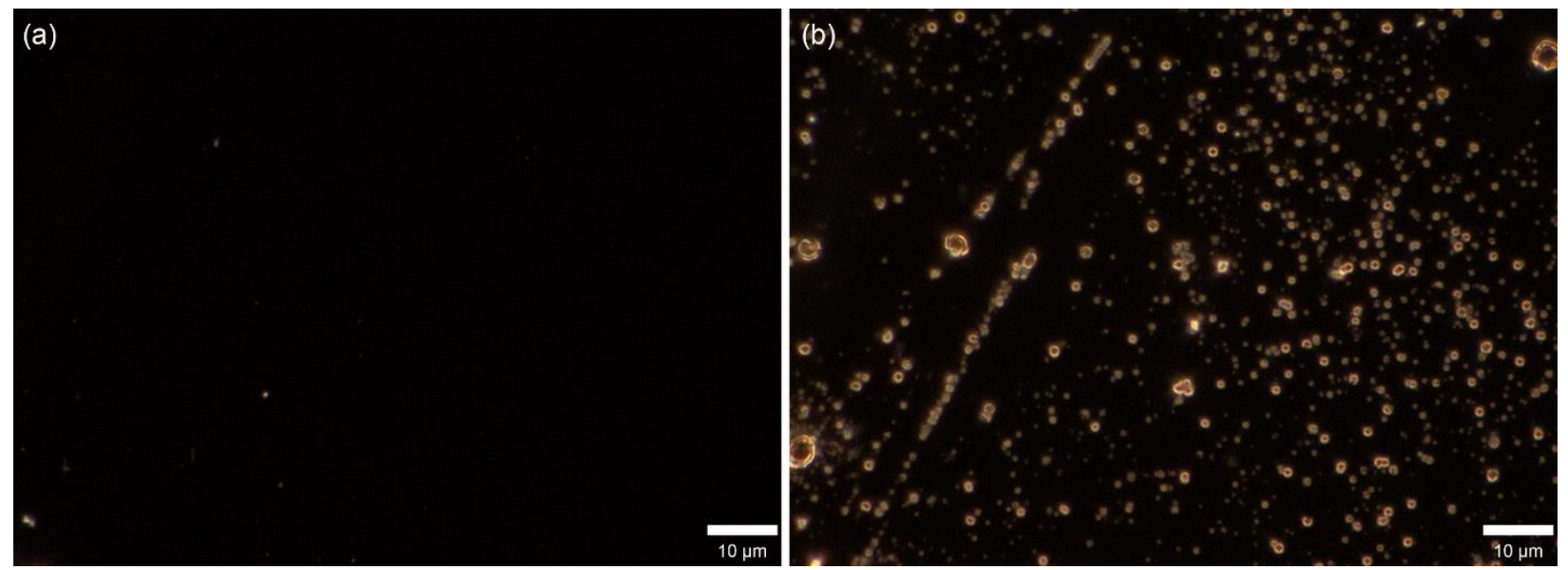

Figure S16. Dark-field images from TCO side of the $\mathrm{CdS} / \mathrm{CdTe} / \mathrm{TiO}_{2} / \mathrm{Ni} / \mathrm{NiO}_{\mathrm{x}}$ photoanode before (a) and after (b) 350-hour stability test. The bright nanoparticles in the right figure were caused by corrosion of CdS nanoparticles. 


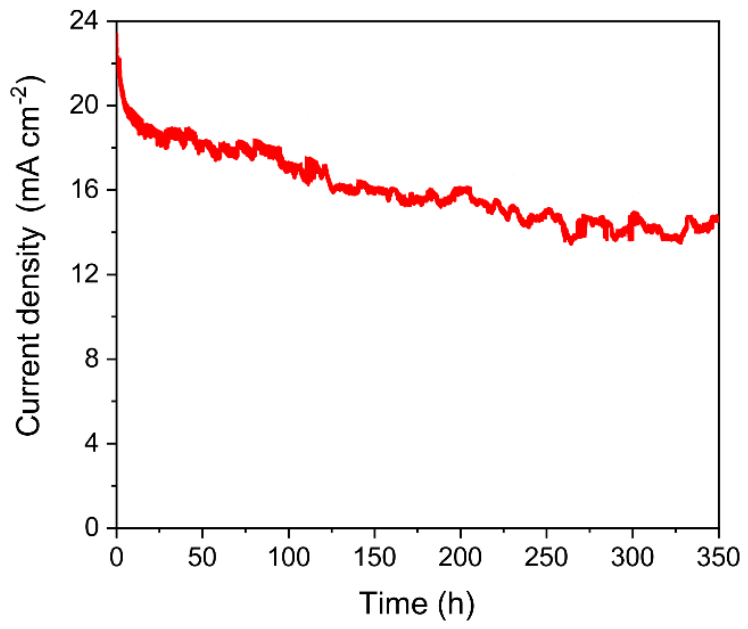

Figure S17. Stability test of $\mathrm{CdS} / \mathrm{CdTe} / \mathrm{TiO}_{2} / \mathrm{Ni} / \mathrm{NiO}_{\mathrm{x}}$ photoanode during long term $\mathrm{PEC}$ reaction. The photocurrent decreased $\sim 35 \%$ of original photocurrent level after 350-hour operation.
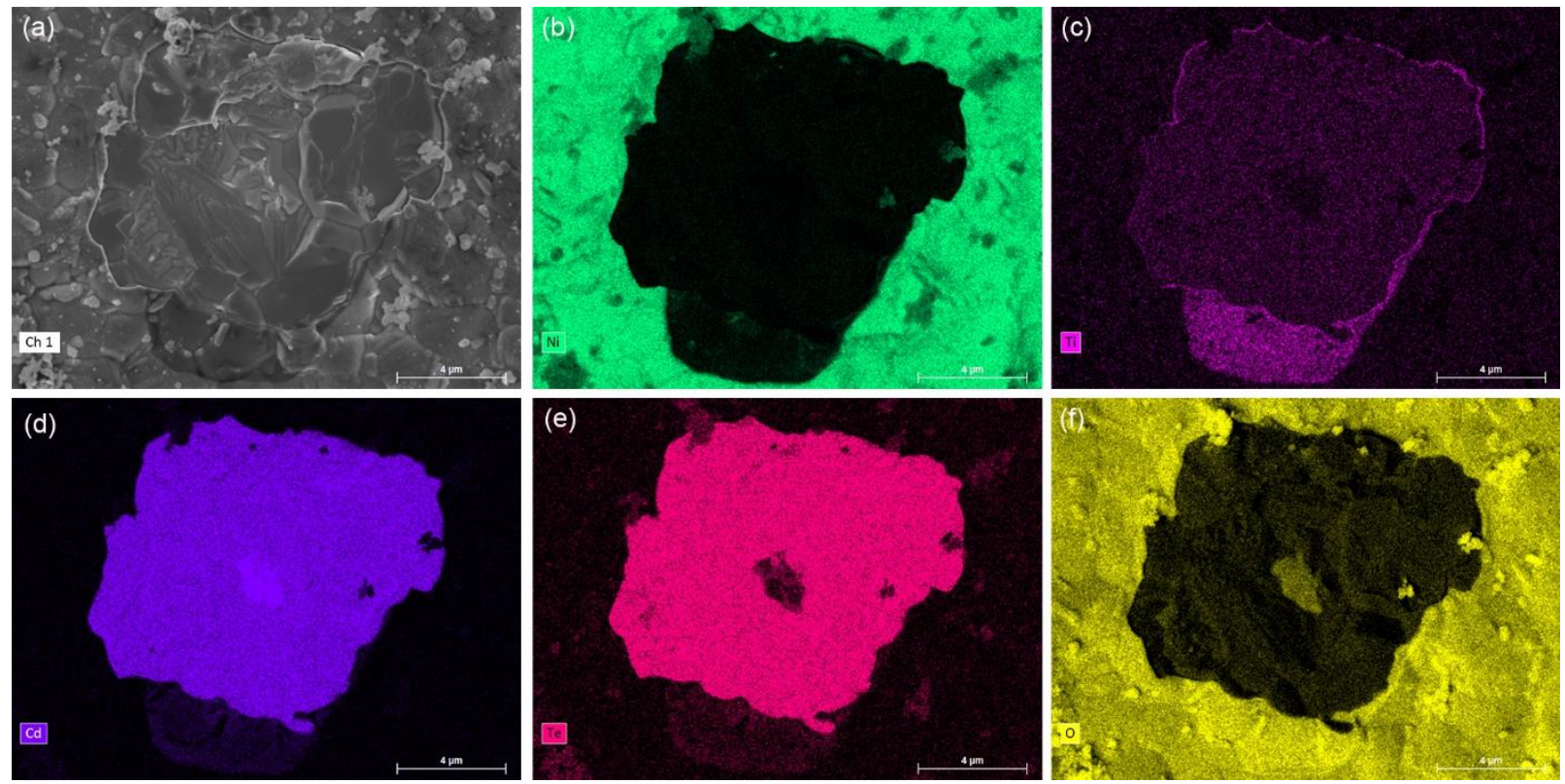

Figure S18. (a) $\mathrm{SEM}$ of the $\mathrm{CdS} / \mathrm{CdTe} / \mathrm{TiO}_{2} / \mathrm{Ni} / \mathrm{NiO}_{\mathrm{x}}$ photoanode after 350 -hour stability test; (b)-(f) Corresponding EDX elemental mappings of $\mathrm{Ni}, \mathrm{Ti}, \mathrm{Cd}, \mathrm{Te}$ and $\mathrm{O}$. Note that the $\mathrm{TiO}_{2}$ protective layer lifted off, exposing CdTe. 

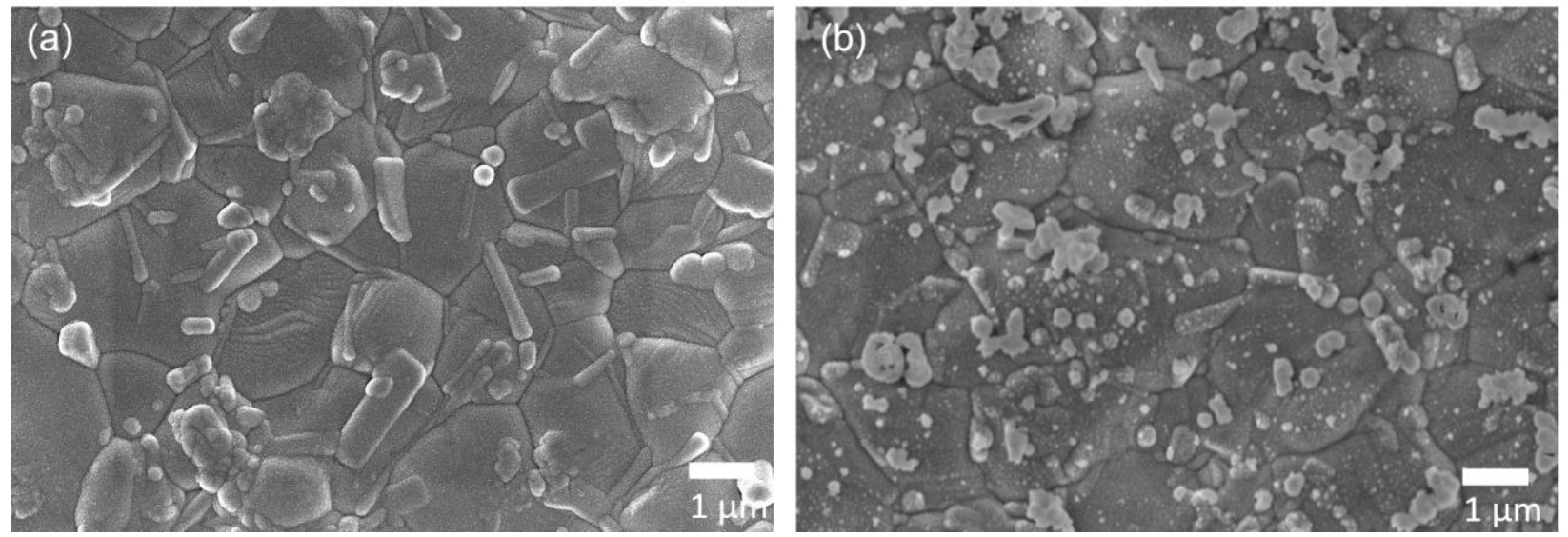

Figure S19. SEM images of $\mathrm{CdS} / \mathrm{CdTe} / \mathrm{TiO}_{2} / \mathrm{Ni} / \mathrm{NiO}_{\mathbf{x}}$ photoanodes before (a) and after (b) 350-hour stability test operation.
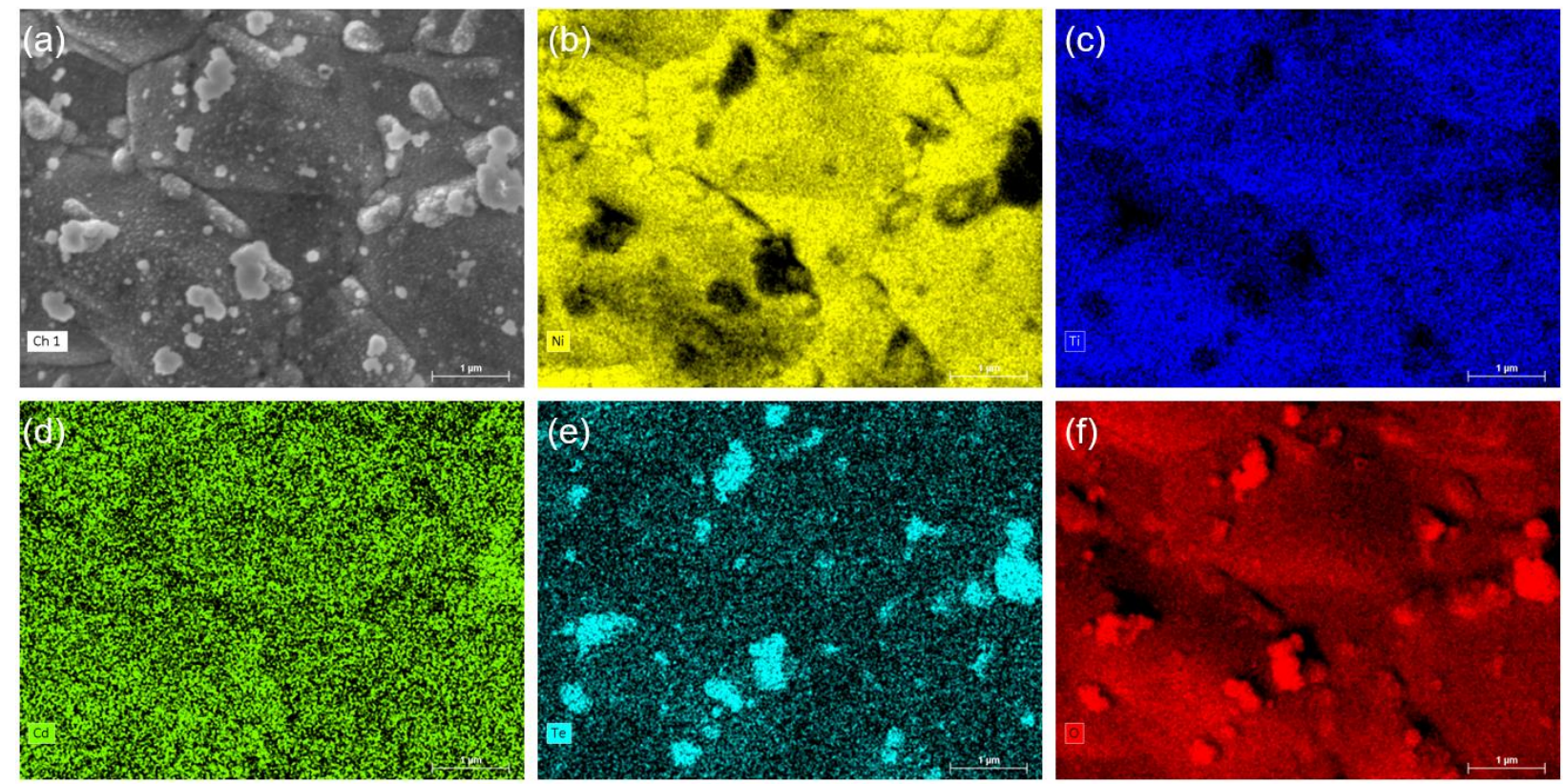

Figure S20. SEM of $\mathrm{CdS} / \mathrm{CdTe} / \mathrm{TiO}_{2} / \mathrm{Ni} / \mathrm{NiO}_{\mathrm{x}}$ photoanode after 350-hour stability test (a) and the corresponding EDX elemental mappings of (b) $\mathrm{Ni}$, (c) $\mathrm{Ti}$, (d) $\mathrm{Cd}$, (e) Te and (f) O, indicating that the oxidized species $\left(\mathrm{CdTeO}_{\mathrm{x}}\right)$ were re-deposited onto the electrode surface. 

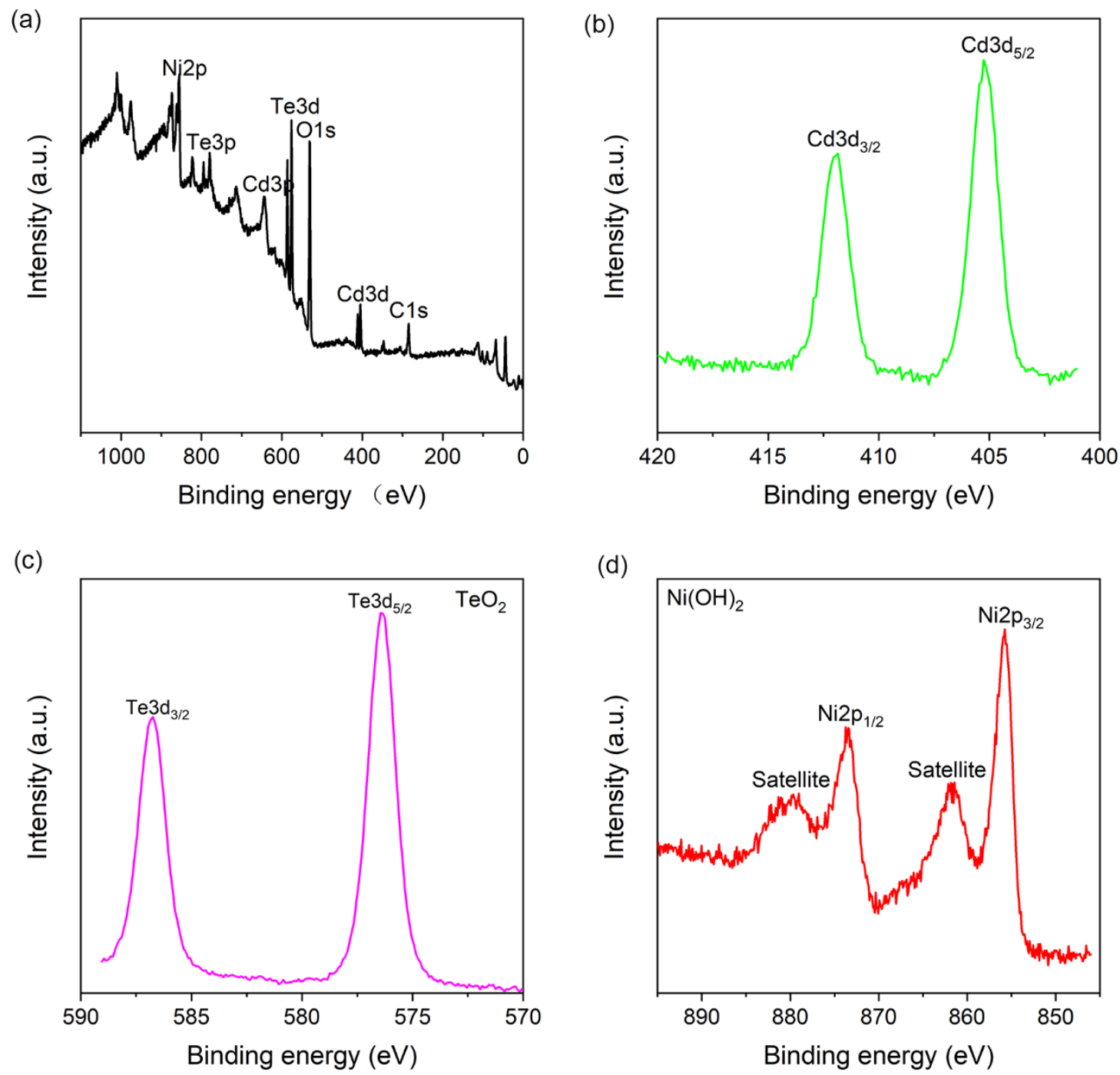

Figure S21. (a) XPS survey scan of $\mathrm{CdS} / \mathrm{CdTe} / \mathrm{TiO}_{2} / \mathrm{Ni} / \mathrm{NiO}_{x}$ photoanode after 350 -hour stability test and the corresponding core-level XPS spectra of (b) $\mathrm{Cd}$, (c) $\mathrm{Te}$ and (d) Ni. The element $\mathrm{Te}$ has been oxidized into $\mathrm{TeO}_{2}$ completely and element $\mathrm{Ni}$ existed in the form of $\mathrm{Ni}(\mathrm{OH})_{2}$.

Table S1. Energetic parameters of the various layer components. ${ }^{15,25}$

\begin{tabular}{ccccc}
\hline Layer & $\mathrm{SnO}_{2}$ & $\mathrm{CdS}$ & $\mathrm{CdTe}$ & $\mathrm{TiO}_{2}$ \\
\hline Bandgap $(\mathrm{eV})$ & 3.6 & 2.4 & 1.5 & 3.34 \\
Electron affinity $(\mathrm{eV})$ & 4.7 & 4.5 & 4.4 & 4.4 \\
VBM to vacuum $(\mathrm{eV})$ & 8.4 & 6.9 & 5.9 & 7.74 \\
Work function $(\mathrm{eV})$ & 4.7 & 4.61 & 5.64 & 4.8 \\
\hline
\end{tabular}




\section{Reference}

1. McGott, D. L.; Kempe, M. D.; Glynn, S.; Bosco, N.; Barnes, T. M.; Haegel, N. M.; Wolden, C. A.; Reese, M. O. Thermomechanical lift-off and recontacting of CdTe solar cells. ACS Appl. Mater. Interfaces 2018, 10, 44854-44861.

2. Siddiqi, G.; Luo, Z.; Xie, Y.; Pan, Z.; Zhu, Q.; Röhr, J. A.; Cha, J. J.; Hu, S. Stable water oxidation in acid using manganese-modified $\mathrm{TiO}_{2}$ protective coatings. ACS Appl. Mater. Interfaces 2018, 10, 18805-18815.

3. Chen, X.; Fu, Y.; Kong, T.; Shang, Y.; Niu, F.; Diao, Z.; Shen, S. Protected hematite nanorod arrays with molecular complex co-catalyst for efficient and stable photoelectrochemical water oxidation. Eur. J. Inorg. Chem 2019, 15, 2078-2085.

4. Hu, S.; Chi, C. Y.; Fountaine, K. T.; Yao, M.; Atwater, H. A.; Dapkus, P. D.; Lewis, N. S.; Zhou, C. Optical, electrical, and solar energy-conversion properties of gallium arsenide nanowire-array photoanodes. Energy Environ. Sci. 2013, 6, 1879-1890.

5. Santori, E. A.; Maiolo, J. R.; Bierman, M. J.; Strandwitz, N. C.; Kelzenberg, M. D.; Brunschwig, B. S.; Atwater H. A.; Lewis, N. S. Photoanodic behavior of vapor-liquid-solid-grown, lightly doped, crystalline Si microwire arrays. Energy Environ. Sci. 2012, 5, 6867-6871.

6. Su, J.; Minegishi, T.; Domen, K. Efficient hydrogen evolution from water using CdTe photocathodes under simulated sunlight. J. Mater. Chem. A 2017, 5, 13154-13160.

7. Biesinger, M. C.; Payne, B. P.; Grosvenor, A. P.; Lau, L. W. M.; Gerson, A. R.; Smart, R. S. C. Resolving surface chemical states in XPS analysis of first row transition metals, oxides and hydroxides: $\mathrm{Cr}, \mathrm{Mn}, \mathrm{Fe}$, Co and Ni. Appl. Surf. Sci. 2011, 257, 2717-2730.

8. Nesbitt, H. W.; Legrand, D.; Bancroft, G. M. Interpretation of Ni2p XPS spectra of Ni conductors and Ni insulators. Phys. Chem. Minerals 2000, 27, 357-366.

9. Lichterman, M. F.; Carim, A. I.; McDowell, M. T.; Hu, S.; Gray, H. B.; Brunschwig, B. S; Lewis, N. S. Stabilization of n-cadmium telluride photoanodes for water oxidation to $\mathrm{O}_{2}(\mathrm{~g})$ in aqueous alkaline electrolytes using amorphous $\mathrm{TiO}_{2}$ films formed by atomic-layer deposition. Energy Environ. Sci. 2014, 7, 3334-3337.

10. Reese, M. O.; Perkins, C. L.; Burst, J. M.; Farrell, S.; Barnes, T. M.; Johnston, S. W.; Kuciauskas, D.; Gessert, T. A.; Metzger, W. K. Intrinsic surface passivation of CdTe. J. Appl. Phys. 2015, 118, 155305.

11. Kumar, S. G.; Rao, K. S. R. K. Physics and chemistry of CdTe/CdS thin film heterojunction photovoltaic devices: fundamental and critical aspects. Energy Environ. Sci. 2014, 7, 45-102.

12. Niles, D. W.; Li, X.; Sheldon, P.; Höchst, H. A photoemission determination of the band diagram of the Te/CdTe interface. J. Appl. Phys. 1995, 77, 4489-4493.

13. Lichterman, M. F.; Hu, S.; Richter, M. H.; Crumlin, E. J.; Axnanda, S.; Favaro, M.; Drisdell, W.; Hussain, Z.; Mayer, T.; Brunschwig, B. S.; Lewis, N. S.; Liu, Z.; Lewerenz H.-J. Direct observation of the energetics at a semiconductor/liquid junction by operando X-ray photoelectron spectroscopy. Energy Environ. Sci. 2015, 8, 2409-2416. 
14. Li, C.; Li, A.; Luo, Z.; Zhang, J.; Chang, X.; Huang, Z.; Wang, T.; Gong, J. Surviving high-temperature calcination: $\mathrm{ZrO}_{2}$-induced hematite nanotubes for photoelectrochemical water oxidation. Angew. Chem. Int. Ed. 2017, 56, 4150-4155.

15. Hu, S.; Richter, M. H.; Lichterman, M. F.; Beardslee, J.; Mayer, T.; Brunschwig, B. S.; Lewis, N. S. Electrical, photoelectrochemical, and photoelectron spectroscopic investigation of the interfacial transport and energetics of amorphous $\mathrm{TiO}_{2} / \mathrm{Si}$ heterojunctions. J. Phys. Chem. C 2016, 120, 3117-3129.

16. Ernst, K.; Engelhardt, R.; Ellmer, K.; Kelch, C.; Muffler, H.-J.; Lux-Steiner, M.-Ch.; Könenkamp, R. Contacts to a solar cell with extremely thin CdTe absorber. Thin Solid Films 2001, 387, 26-28.

17. Ernst, K.; Belaidi, A.; Könenkamp, R. Solar cell with extremely thin absorber on highly structured substrate. Semicond. Sci. Technol. 2003, 18, 475-479.

18. Belaidi, A.; Bayón, R.; Dloczik, L.; Ernst, K.; Lux-Steiner, M.-Ch.; Könenkamp, R. Comparison of different thin film absorbers used in eta-solar cells. Thin Solid Films 2003, 431, 488-491.

19. Tiefenbachera, S.; Pettenkofer, C.; Jaegermann, W. Ultrahigh vacuum preparation and characterization of interfaces: Electrical properties and implications for solar cells. J. Appl. Phys. 2002, 91, 1984-1987.

20. Brus, V. V.; Ilashchuk, M. I.; Kovalyuk, Z. D.; Maryanchuk, P. D.; Parfenyuk, O. A. Surface-barrier heterojunctions $\mathrm{TiO}_{2} / \mathrm{CdZnTe}$. Semicond. Sci. Technol. 2013, 28, 015014.

21. Brus, V. V.; Ilashchuk, M. I.; Kovalyuk, Z. D.; Maryanchuk, P. D.; Ulyanytsky, K. S.; Gritsyuk, B. N. Mechanisms of charge transport in anisotype n- $\mathrm{TiO}_{2} / \mathrm{p}-\mathrm{CdTe}$ heterojunctions. Semicond. 2011, 45, 1077-1081.

22. Zhang, Z.; Yates, J. T. Band bending in semiconductors: chemical and physical consequences at surfaces and interfaces. Chem. Rev. 2012, 112, 5520-5551.

23. Wang, K.; Zhang, R.; Sun, N.; Li, X.; Wang, J.; Cao, Y.; Pei, R. Near-infrared light-driven photoelectrochemical aptasensor based on the upconversion nanoparticles and $\mathrm{TiO}_{2} / \mathrm{CdTe}$ heterostructure for detection of cancer cells. ACS Appl. Mater. Interfaces 2016, 8, 25834-25839.

24. Ai, G.; Mo, R.; Xu, H.; Chen, Q.; Yang, S.; Li, H.; Zhong, J. Vertically aligned $\mathrm{TiO}_{2} /(\mathrm{CdS}, \mathrm{CdTe}, \mathrm{CdSTe})$ core/shell nanowire array for photoelectrochemical hydrogen generation. J. Power Sources 2015, 280, 5-11.

25. Mahabaduge, H. P.; Rance, W. L.; Burst, J. M.; Reese, M. O.; Meysing, D. M.; Wolden, C. A.; Li, J.; Beach, J. D.; Gessert, T. A.; Metzger, W. K.; Garner, S.; Barnes, T. M. High-efficiency, flexible CdTe solar cells on ultra-thin glass substrates. Appl. Phys. Lett. 2015, 106, 133501. 